\title{
AIR MANAQIB
}

\author{
Nashiruddin \\ Email: abiafif99gmail.com
}

\section{Abstrak}

Salah satu program religius yang bertujuan untuk meningkatkan potensi speritualitas Santri Al Fithrah secara khusus, dan Jama'ah atau pengikut Syaikh Achmad Asrori Al-Ishaqy secara umum, adalah Majlis Manaqiban, yaitu ritual agama yang berisikan Do'a Bersama, Istighatsah, membaca surat Yasin, Membaca manaqib (Biografi) Syaikh Abdul Qodir al-jilany, kemudian disempurnakan dengan pembacaan maulid Nabi. Motivasi majlis ini adalah tawassul dengan para guru dalam upaya mendekatkan diri kepada Allah SWT. Sehingga kegiatan semacam ini juga disebut Shilaturruhiyyah. Ada hal yang menarik dalam kegiatan tersebut, yaitu setiap kegiatan Majlis Manaqiban dapat dipastikan bahwa Jama'ah yang mengikuti mejlis tersebut mayoritas membawa atau menaruh air mineral di sekitarnya dengan kondisi tutup botol terbuka. Tampaknya, air tersebut ada nilai istimewa tersendiri baginya, terbukti air tersebut kemudian disebut dengan sebutan "Air Manaqib."

Persoalan ini termasuk persoalan Humaniora (persoalan yang bersifat prilaku manusia), oleh karena itu, untuk mengungkap persoalan tersebut secara menyeluruh dan mendalam, maka dalam penelitian ini digunakan metode kualitatif. Karena metode kualitatif lebih dapat beradaptasi dengan keadangan lingkungan

Dari hasil penelitian yang ditemukan, Santri atau Jama'ah majlis manaqiban tersebut berasumsi bahwa air manaqib dapat digunakan sebagai: (1) Media pengobatan berbagai macam penyakit lahir, (2) Mempermudah proses persalinan, (3) Pagar gaib dari pengaruh buruk dan sebagai penglaris dagangan. 
Sedangkan cara penggunaannya menurut mereka tidak ada cara atau aturan yang baku, tetapi cara yang sering dipakai adalah dengan cara diminum.

Setelah penelitian dilakukan lebih mendalam, maka ditemukan bahwa prilaku seperti itu, yaitu pengobatan menggunakan media air juga pernah dilakukan sebagian ulama salaf walaupun tidak disebut air manaqib, akan tetapi subtansinya sama, yaitu tabarrukan

Ditinjau dari pandangan sains (ilmiah), dengan mengacu pada penemuan Masaru Emoto, bahwa sifat air itu dapat merespon sebuah informasi, instruksi atau doa, dan air yang telah menerima pesan atau doa tadi, kualitasnya semakin tinggi, berarti kualitas air manaqib juga semakin tinggi. Dengan demikian, pemanfaatan air manaqib, baik ditinjau dari pandangan agama atau sanis dapat dipertanggungjawabkan kebenarannya.

\section{Kata kunci : Air Manaqib, Manaqiban, Al Fithrah}

\section{Pendahuluan}

Majlis manaqiban (selanjutnya disebut manaqiban) adalah salah satu dari berbagai macam ritual religius yang diadakan oleh "Jamaah Al Khidmah" di bawah bimbingan syaikh Ahmad Asrori al-Ishaqy ra. manaqiban juga merupakan salah satu dari beberapa macam media syi' ar Pondok Pesantren Assalafi Al Fithrah. ${ }^{1}$. Bapak H. Ainul Huri mengatakan: "Manaqiban merupakan ujung tombak syi' ar yang dibawa oleh

${ }^{1}$ Keterangan dari H. Hasanuddin, pada waktu memberikan kuliah umum di STAI Al Fithrah Surabaya : 2010. Ia adalah ketua satu Jama'ah Al Khidmah 
Romo Yai Ahmad Asrori Al-Ishaqy ra."1 Di dalam salah satu ayat Alqu'an, Allah SWT berfirman,

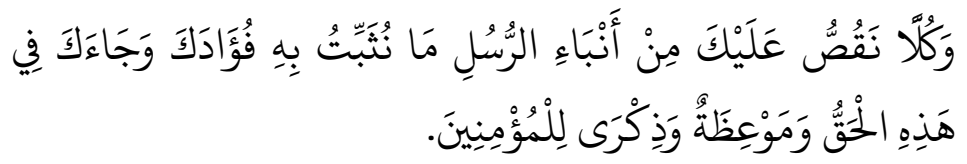

Semua kisah dari para rasul kami ceritakan kepadamu, ialah kisah-kisah yang dengannya kami teguhkan hatimu, dan telah datang kepadamu kebenaran serta pengajaran dan peringatan bagi orang-orang yang beriman." ${ }^{2}$ QS. Hud: 120

Ayat ini menjadi salah satu bukti nyata legalitas tradisi manaqiban yang di dalamnya diceritakan kisah teladan orangorang saleh dan para waliyullah. ${ }^{3}$

Imam Junaid juga mengatakan:

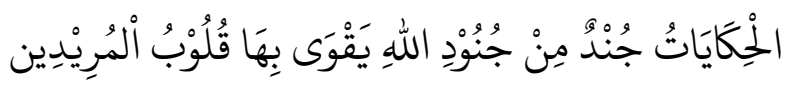

Kisah-kisah teladan adalah satu pasukan dari pasukanpasukan Allah SWT yang dengannya hati para murid bisa kokoh. ${ }^{4}$

Dalil-dalil yang menerangkan tentang kebenaran majlis manaqiban itu banyak, baik dalam Alqu'qn maupun maqolah ulama. Namun yang menjadi permasalahn di sini bukanlah

${ }^{1}$ Keterangan dari Ainul Huri, pada waktu memberikan pencerahan terhadap kepengurusan Pondok Al Fithrah Surabaya. Ia adalah ketua Yayasan Al Khidmah

${ }^{2}$ FKI (Forum karya ilmiah Lirboyo), Menjawab Vonis Bid'ah,Tahta, Kediri, 2010, hlm. 232.

3 Ibid., 232

${ }^{4}$ FKI (Forum karya ilmiah Lirboyo), 235 
tentang legalitas manaqiban ini, akan tetapi motivasi penulisan ini adalah apa yang mewarnai dalam pelaksanaan manaqiban itu sendiri, yaitu adanya Air, Jama'ah menyebutnya "Air Manaqib."

Setiap ada majlis manaqiban, baik bulanan atau yang incidental, terutama majlis yang disebut Haul Akbar, di sekitar jama'ah yang mengikuti acara tersebut, dapat dikatakan "Pasti ada air minum" yang sengaja ditaruh di tempat itu. Air tersebut bukanlah untuk jamuan jamaah seusai acara, melainkan untuk diambil kembali oleh pemiliknya masingmasing, dibawa pulang kerumah untuk keluarganya. Dengan demikian, tampakanya air manaqib bagi mereka mempunyai nilai tersendiri, artinya, mempunyai nilai yang lebih istimewa daripada selain air manaqib.

Pihak koperasi Al Khidmah yang berada di lingkungan Pondok Pesantren Assalafi Al Fithrah, ketika mendekati pelaksanaan haul akbar, jauh-jauh hari sudah menyiapkan air mineral merk Al Ajwa dengan jumlah yang tidak sedikit. Toko-toko di sekitar Pesantren pun sangat antusias memanfaatkan momen yang dirasakan satu tahun satu kali itu.

Menurut salah satu responden, Fenomena seperti itu sebenarnya bukanlah hal yang baru. Sejak jaman Assyaikh Muhammad Utsman Al-Ishaqy, ayah kandung dari Assyaikh 
Ahmad Asrori Al-Ishaqy ra, sudah tertanam, dan sudah menjadi tradisi, bahkan seakan-akan sudah menjadi kewajiban bagi para murid dan jamaah, untuk membawa air ketika menghadiri majlis manaqiban atau haul akbar. ${ }^{1}$

Fenomena sebagaimana uraian di atas, sedikit banyak telah menimbulkan pertanyaan:

1. Bagaimana Pandangan Jama'ah Manaqib Terhadapa Air Manaqib?

2. Bagaimana Pandangan Agama Terhadap Fenomena Air Manaqib?

\section{Air Manaqib dalam pandangan Jama'ah Manaqiban}

Istilah "Air manaqib" adalah air yang telah dibacakan manaqib, atau air yang telah diikutkan dalam majlis manaqiban. Definisi ini tentunya hanya asumsi penulis berdasarkan fenomena yang dilihatnya, yaitu setiap pelaksanaan manaqiban di Pondok Al Fithrah Surabaya, di sudutsudut masjid, selalu menjadi tempat penyimpanan air minum milik jamaah. bahkan milik keluarga ndalem pun yang jumlahnya sampai puluhan dus juga ditata rapi oleh sebagian santri yang memang ditugasi untuk mengurus air manaqib

${ }^{1}$ Ceramah dari Ust. H. Adnan ketika manaqiban di Mall galaxy Sby.: 2010. Ia adalah salah satu santri syaikh Muhammad utsman al-Ishaqy 
setiap ada majlis manaqiban di Pondok Pesantren Assalafi Al Fithrah Surabaya. Air tersebut ditaruh sejak awal dengan kondisi tutup botol terbuka. Menurutnya, hal itu merupakan anjuran langsung dari syaikh Ahmad Asrori al-Ishaqy ra. ${ }^{1}$

\section{Asal usul}

Pada masa hidup syaikh Abdul Qodir al-Jilany ra. ia masyhur dengan kekeramatannya, sehingga banyak masyarakat yang berkunjung semata-mata mengharapkan barokahnya. bentuk keyakinan mereka untuk mendapatkan barokah dari syaikh Abdul Qodir al-Jilany itu diinterpretasikan dengan membawa air kehadapannya, kemudian dibawa pulang setalah didoakan. Hal seperti itu selalu dilakukan setiap kali menghadiri majlis syaikh Abdul Qodir al-Jilany ra. ${ }^{2}$

Masyarakat yang menghadiri majlis ta'lim yang diadakan syaikh Abdul Qodir bukan hanya dari orang islam saja, diantara mereka ada yang dari Nasroni. Kepada orang Nasroni itu syaikh Abdul Qodir sempat berpesan. Ia berkata: "Teruskanlah apa yang menjadi kebiasaanmu (ngalap barokah), walaupun nanti saya sudah meninggal dunia".

${ }^{1}$ Sulaiman, Ta'mir masjid Al Fithrah ( Surabaya, 02/01/2012)

${ }^{2}$ Keterangan dari Ustad H. Adnan, 13/01/2012). Ia termasuk santri sepuh Syaikh Muhammad Utsman. Menurutnya, cerita itu, ia dapat dari syaikh Muhammad Utsman al-Ishaqy 
Sepeninggal syaikh Abdul Qodir, orang Nasroni tadi melakukan pesan yang ia terima, tetapi bukan kebiasaan menghadiri tempat syaikh Abdul Qodir al-Jilany, melainkan hanya kebiasaan menimba barokahnya, namun kali ini bukan membawa air ke tempat syaikh Abdul Qodir, yang ia lakukan adalah setiap malam tanggal sebelas (11) hijriyah, yaitu malam hari wafatnya, ia selalu menaruh air di atas atap rumah dengan harapan mendapatkan barokah dari syaikh Abdul Qodir al-Jilany ra. kemudian pada waktu pagi, air itu diminumnya. Hal itu dilakukan sampai akhir hayatnya. ${ }^{1}$ Ustad. H. Adnan berkata:

Mungkin dari latar belakang kebiasaan santri-santri syaikh Abdul Qodir al-Jilany dan jama'ahnya, yaitu selalu membawa air ketika menghadiri majlis ta'lim yang diasuh Syaikh Abdul Qodir al-Jilany, ketika Syaikh Muhammad Utsman mengadakan majlis dzikir atau manaqiban, ia menganjurkan santri-santrinya supaya membawa air, dengan harapan mendapatkan barokah. Kemudian air itu disebut dengan istilah air manaqib. Penyebutan air manaqib ini dinisbatkan pada nama majlis manaqiban itu sediri. ${ }^{2}$

\section{Manfaat Air Manaqib}

Setelah beberapa waktu melakukan observasi, mengamati, interaksi dan wawancara atau sekedar berbincangbincang verbal dengan Jama'ah tentang air manaqib, maka

\footnotetext{
${ }^{1}$ Ibid.

2 Ibid.
} 
dapat dirumuskan bahwa air manaqib secara garis besar bisa digunakan sebagai berikut:

a. Media pengobatan berbagai macam penyakit lahir

b. Media kemudahan proses persalinan

c. Penglaris dagangan, pagar gaib area dari gangguan hal-hal yang buruk.

Beberapa rumusan manfa'at air manaqib ini hanyalah berdasarkan pengalaman dari beberapa responden yang dilakukan menurut instuisi, dan dengan cara masing-masing. Artinya, cara penggunaannya tidak ada konsep khusus, ada yang dengan cara diminum, diminum dan diusapkan pada bagian yang dikehendaki atau pada bagian perut bagi orang yang hendak melahirkan, dicampurkan pada barang jualan apabila bertujuan sebagai penglaris jual makanan. Ada juga yang dipercikkan pada suatu tempat, jika bertujuan untuk mengobati penyakit tanaman pertanian. ${ }^{1}$

\section{Air Manaqib dalam Pandangan Agama}

Dunia merupakan tempat sebab dan perantara (media) ${ }^{2}$, dengan artian, semua apa yang terjadi di dunia, semata-mata atas kehendak Allah, namun walupun demikian, pada umunya,

\footnotetext{
${ }^{1}$ Pendapat mayoritas responden

${ }^{2}$ Dawuh syaikh Ahmad Asrori al-Ishaqy pada waktu pengajian minggu ke2
} 
Allah merealisasikan apa yang dikehendaki-Nya melalui sebab dan perantara.

Segala sesuatu yang terjadi di Dunia, atau segala sesuatu yang Allah ciptakan, pasti ada hikmah dan kegunaanya. Seperti halnya air. Air merupakan mineral yang sangat vital bagi tubuh manusia; air sangat vital pula bagi keberlangusungan hidup dalam kehidupan manusia dan makhluk yang lain; air juga bisa dijadikan sebagai media pengobatan sebagaimana pengobatan medis.

Sebagian ulama salaf, ada yang pernah menjadikan air sebagai media pengobatan. Adapun caranya yaitu dengan dibacakan sebagian ayat al-Quran atau doa, lalu air tersebut diminumkan pada orang yang menderita. ${ }^{1}$

Ada beberapa ayat al-Qur'an dan Hadith yang menjadi pijakan para ulama salaf terkait dengan praktek pengobatan yang mereka lakukan, di antaranya adalah:

\section{Ayat al-Qur'an}

a. Surat al-Ambiya

$$
\text { وَجَعَلْنَا مِنَ الْمَاءٍٍ كُلَّ شَيْءٍ حَيِّ أَفَلا يُوِْْنُونَ }
$$

Dari air Kami jadikan segala sesuatu yang hidup. Maka mengapakah mereka tiada juga beriman?. QS. alAmbiya, ayat: 30

\footnotetext{
${ }^{1}$ Haqqi, Tafsir haqqi, jz 7. Maktabah syamila, hlm.274
} 
Ayat ini mengisyaratkan, betapa besar potensi air dalam kehidupan makhluk hidup; Semua makhluk diciptakan dari air, baik yang hidup dengan ruh, atau makhluk hidup yang bukan dengan ruh. Manusia diciptakan dari air, oleh karena itu, air bagi manusia sangat urgen, baik untuk kesehatan atau untuk kebutuhan yang lain.

b. Surat al-Isra' ayat 82 . Allah berfirman:

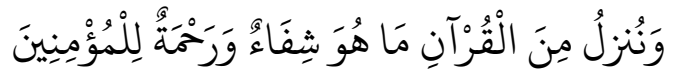

Aku turunkan sebagian dari Al-Quran yaitu (sesuatu yang bisa bermanfaat) sebagai penyembuh dan rahmat bagi orang-orang mukmin.QS. al-Isra' ayat: 82

Berkenaan dengan ayat tersebut, ulama tafsir dalam menafsiri kalimat "Syifa" yang berarti obat atau penyembuh pada ayat ini ada dua klasifikasi:

Pertama: al-Quran merupakan obat untuk penyakit yang bersifat rohani, yaitu menghilangkan kebodohan hati, keraguraguan, dan bisa memahami terhadap hal-hal yang bisa mengantarkan makrifat kepada Allah SWT. Dengan kata lain, dengan memahami isi al-Quran, maka penyakit yang berupa kebodohan dan keragu-raguan tentang iman bisa hilang, dan ia bisa ber-makrifat kepada Allah SWT.

Kedua: al-Quran merupakan obat penyakit dhohir, yaitu bertabarruk dengan membacanya bisa menjadi penyebab sem- 
buhnya berbagai macam penyakit. ${ }^{1}$

\section{Hadits}

Terkait dengan masalah pengobatan dengan media air, penulis juga mengutip beberapa hadits sebagai berikut:

a. Hadits riwayat imam Malik

Dalam sebuah riwayat diceritakan bahwa pada suatu hari, ada seorang perempuan mendatangi Asma binti Abu Bakar ra dengan tujuan mengadukan sakit panas yang sedang dideritanya. Asma yang menerima pengaduan perempuan tadi, ia teringat terhadap salah satu sabda Rasulullah SAW tentang penyakit panas, yaitu diobati dengan air. Lalu Asma mengusapkan air pada kulit di antara kerah baju perempuan tadi supaya panasnya menurun. Asma berbuat demikian karena mengharap barokah dari tuntunan Rasulullah SAW. ${ }^{2}$ adapun hadits yang dimaksud Asma adalah sebagaimana berikut:

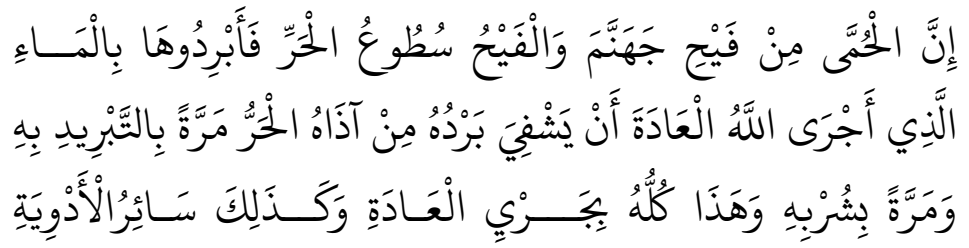

1 Al Qurtuby, Tafsir Al Qurtuby ,Maktabah syamilah.

${ }^{2}$ Syarh Muwattok, jz 4, hal. 365. Maktabah syamilah. 


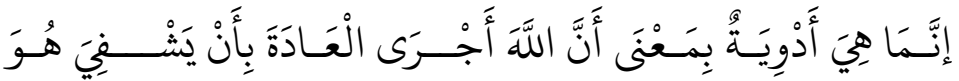

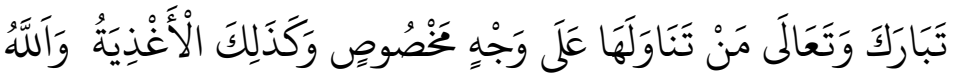

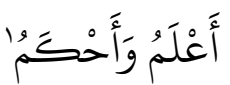

Penyakit demam itu berasal dari serakan neraka jahannam, serakan jahannam adalah semerbak dari hawa panas neraka. Maka (untuk mengobatinya) dinginkanlah dengan air, yang mana pada biasanya, Allah menyembuhkan penyakit yang ditimbulkan hawa panas dengan perkara dingin, caranya, bisa dengan cara di dinginkan (dengan sentuhan air) atau juga bisa dengan cara diminum. Namun semuanya itu tidaklah pasti, itu hanyalah hukum adat, sebagaimana obat-obat lain. Artinya; Allah akan memberlakukan hukum adat bagi orang yang melakukan adat tersebut dengan cara yang telah ditentukan, sebagaimana adat masalah makanan. Semuanya Allah yang lebih tahu dan lebih bijaksana.

b. Hadits riwayat imam Bukhori

$$
\text { مَنْ لَمْ يَستشْفِ بالقرآنِ ، فلا شَفاهُ الله تعالى }
$$

Barang siapa yang tidak mencari kesembuhan (berobat) dengan (tabarruk bacaan) al-Quran, maka Allah tidak akan menyembuhkannya. ${ }^{2}$

c. Hadits riwayat 'Auf bin Malik

Sahabat Auf bin Malik bercerita: "Pada saat kami di zaman jahiliyah, kami biasa menggunakan ruqyah (mantra-mantra), kemudian kami bertanya kepada Rasulullah SAW tentang hukum ruqyah? Lalu Ia menjawab:

Syarh Muwattok, jz 4, hal 365

2 Al Manawy, Faidhul Qodir Maktabah syamilah 627 


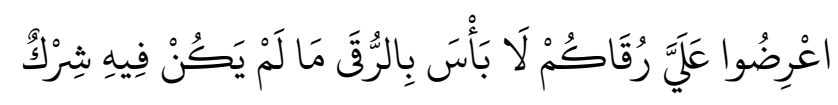

Presentasikanlah mantra-mantramu kepadaku, mantra itu tidak apa-apa selama tidak mengandung kesyirikan. HR. Muslim

Mengenai hadits ini, para ulama sepakat bahwa ruqyah (mantra) yang boleh digunakan kalau memenuhi tiga syarat, yaitu:

1. Ruqyah yang terdiri dari kalam Allah, asma Allah dan sifat-sifat Allah SWT

2. Ruqyah yang berupa bahasa Arab atau bahasa lain yang bisa difahami maknanya

3. Tetap berkeyakinan bahwa ruqyah tidak bisa memberi pengaruh apapun dengan sendirinya, melainkan karena kekuasaan dan ijin Allah SWT ${ }^{1}$

Dalam permasalahan ini, Habib Zainal Abidin bin Ibrahim al-Alawi mengatakan:

Ruqyah yang dilarang adalah semua ruqyah yang tidak difahami artinya, atau tidak berbahasa Arab, karena dimungkinkan mengandung jenis sihir atau menyebabkan kemusyrikan. Adapun mantra yang menggunakan kalam Allah atau asma-Nya, maka boleh, bahkan disunnahkan, sebab tidak ada obat yang diturunkan oleh Allah dari langit yang lebih manjur daripada al-Quran. al-Quran merupakan obat untuk

${ }^{1}$ Al Alawi al Husaini, Habib Zainal Abidin bin Ibrahim bin Smith, Al Ajwibah al Gholiyah, Khalista, Surabaya, 2009, hlm.152. 
segala penyakit dan penghapus noda-noda dalam hati. ${ }^{1}$

d. Dalam hadits lain yang diceritakan oleh Aby Zubair, Rasulullah SAW bersabda:

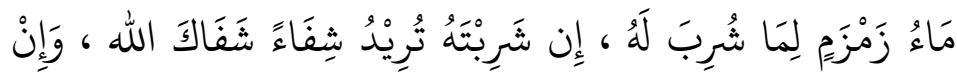

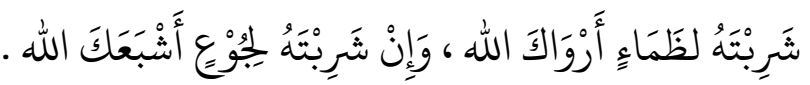

Manfaat air zamzam itu tergantung niat yang meminumnya, jika kamu meminumnya untuk kesembuhan maka Allah akan sembuhkan kamu, dan jika engkau meminumnya karena haus maka Allah akan segarkan kamu, dan jika engkau meminumnya karena lapar maka Allah akan kenyangkan kamu. HR. Abdullah bin Muammal

\section{Pendapat ulama}

Berkenaan dengan dalil legalitas pengobatan dengan media air, selain keterangan yang dikutip dari al-Quran dan Hadits, penulis juga mengutip dari beberapa komentar ulama, diantaranya ialah:

a. Pendapat imam Tajudin al-Subky ra

Imam Tajudin al-Subky mengatakan: "Saya sering melihat para ulama menuliskan ayat ini $^{2}$ kemudian dimasukkan kedalam gelas yang berisi air, lalu diminumkan pada seseorang yang sedang sakit supaya

${ }^{1}$ Ibid.

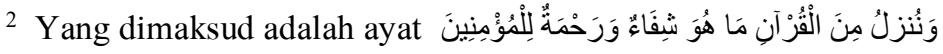


sembuh". 1

b. Pendapat Jabir Bin Abdillah

Jabir Bin Abdillah menceritakan tentang apa yang diterima dari Atho' yang berkenaan dengan peristiwa di waktu turunnya Basmalah, ia berkata:

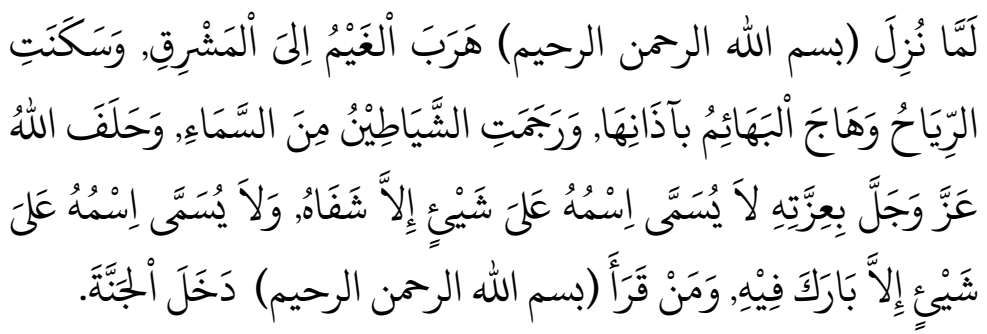

Pada waktu basmalah diwahyukan oleh Allah SWT maka terjadilah keajaiban. Mendung bergeser kearah timur, Angin berhenti, Lautan bergelombang, Hayawan-hayawan diam mendengarkan dengan seksama, Syaitan terlempar dari langit, dan Allah bersumpah "Demi kemuliaan-Nya tidaklah disebutkan nama Allah kepada sesuatu, kecuali Allah akan sembuhkan sesuatu itu. Tidaklah disebutkan nama Allah kepada sesuatu kecuali Allah berkahi sesuatu itu. $^{2}$

c. Pendapat Syaikh ibnu Qoyyum Al Jauziyah Syaikh ibnu Qoyyum Al Jauziyah berkata :

Telah diyakini bahwa sebagian perkataan manusia memiliki sekian banyak kasiat dan aneka ragam

${ }^{1}$ Haqqy, Tafsir Haqqy, jz 7, Maktabah syamilah, hlm. 274.

2 Al-Jilany. Abdul Qodir ra. ,Al Ghun-yah, Darul Kutub ilmiyah, Libanon:, 1998, hlm.217. 
kemanfa'atan yang bisa dibuktikan, apalagi ayat-ayat alQuran selaku kalam Allah yang keutamaannya di atas semua perkataan makhluk, tentu saja ayat-ayat al-Quran bisa berfungsi sebagai penyembuh yang sempurna."

\section{d. Pendapat Abdullah}

Putra imam Ahmad yang bernama Abdullah mengatakan: "Saya melihat Bapakku menulis ta'widz (azimat) untuk orang yang ketakutan dan orang yang terserang demam.'

Abdullah juga meriwayatkan dari ulama salaf perihal ayahnya dalam masalah azimat, bahwa imam Ahmad sering menulis ayat al-Quran lalu direndam dengan air untuk diminumkan kapada orang-orang yang terkena penyakit.

e. Pendapat Imam Mujahid

Imam Mujahid mengatakan: "Tidak apa-apa menulis ayat-ayat al-Quran kemudian membasuhnya dengan air, lalu meminumkan air tersebut kepada orang yang sakit”. Imam Mujahid juga menceritakan tentang Ibnu Abas, bahwa ia memerintahkan agar dituliskan ayat al-Quran lalu merendamnya dalam air, kemudian diminumkan kepada orang yang sulit melahirkan. ${ }^{2}$

f. Pendapat Syaikh Ayyub

Syaikh Ayyub mengatakan: "Saya melihat Abu Qilabah menulis sebuah ayat al-Quran, lalu merendamnya dalam air, kemudian diminumkan kepada seorang laki-laki yang sedang sakit."

g. Pendapat imam Ibnu Taymiyah

${ }^{1}$ M. Idrus Ramli, Membedah Bid'ah \& Tradisi, Khalista, Surabaya, 2010,hlm.85.

${ }^{2}$ Ibid. 154 
Imam Ibnu Taymiyah dalam fatwanya mengatakan:

Banyak orang meriwayatkan dari Ibnu Abas, sesungguhnya ia biasa menulis ayat-ayat al-Quran dan menyuruh agar direndam dalam air, lalu diminumkan kepada orang yang sakit. Ibnu Abas menjelaskan, bahwa hal yang demikian memiliki barokah, dan imam Ahmad memperbolehkannya. ${ }^{1}$

h. Pendapat syaikh Muhammad Utsman al-Ishaqy ra

Syaikh Muhammad Utsman al-Ishaqy ra. pernah berkata kepada murid-muridnya: "Sebaiknya kalian selalu menyimpan air manaqib di rumah, barangkali suatu waktu di antara keluarga kalian ada yang sakit, maka kasih dia minum air manaqib itu!".2

i. Pendapat syaikh Ahmad Asrory al-Ishaqy ra

Syaikh Ahmad Asrori al-Ishaqy ra. ketika ada seseorang yang matur kepadanya dalam rangka ngalap barokah untuk kesembuhan salah satu anggota keluarganya yang sakit, Ia sering menganjurkan untuk minum air manaqib atau air khususi. ${ }^{3}$

\section{Air Hasil Penelitian Sains}

Masaru Emoto adalah seorang peneliti Jepang yang terkenal dan telah mendapatkan penghargaan dunia internasional. Ia sarjana dari Universitas Yokohama yang tekun melakukan penelitian tentang perilaku air. Dalam penelitian-

\footnotetext{
${ }^{1}$ Al Alawi, Zainal Abidin, Al Ajwibah Al Gholiyah, Khalista, Surabaya, 2009,hlm.155.

${ }^{2}$ Wawancara, Ust. H. Muhammad Saleh, Surabaya, 2/12/2011

${ }^{3}$ Wawancara, Khoddam syaikh Ahmad Asrori al-shaqy ra,. Surabaya, $12 / 11 / 2011$.
} 
nya, Masaru Emoto terus menerus menemukan bahwa air dapat merespon kata-kata positif atau negatif. Ketika air tersebut merespon kata-kata positif, maka ia mengekpresikan dengan membentuk Kristal yang indah. Sebaliknya, jika air diperlihatkan kata-kata negative, ia tidak akan membentuk Kristal yang baik ${ }^{1}$

Dalam percobaannya, ia memperlihatkan dua kata yang berlawanan makna pada air yang sama sumbernya. Kata-kata yang dimaksud adalah: "Bagus" lawan "Tidak Bagus", "Suka" lawan "Tidak suka", "Kuat" lawan "Lemah", "Malaikat" lawan "Iblis", dan "Damai" lawan "Perang". Hasilnya, tidak terbentuk Kristal. Air hanya membentuk Kristal jika diperlihatkan kata-kata yang positif. ${ }^{2}$

Air murni dari mata air di Pulau Honshu didoakan secara agama Shinto, lalu didinginkan sampai $-50 \mathrm{C}$ di laboratorium, lantas difoto dengan mikroskop elektron dengan kamera kecepatan tinggi. Ternyata molekul air membentuk kristal segi enam yang indah. Percobaan diulangi dengan membacakan kata, "Arigato (terima kasih dalam bahasa Jepang)" di depan botol air tadi. Kristal kembali membentuk sangat indah. Lalu dicoba

\footnotetext{
${ }^{1}$ Azam Translator, (terjemah) The True Power of Water, MQ Publishing, Bandung, 2006, hlm.14.

${ }^{2}$ Azam Translator, (terjemah) The True Power of Water...15
} 
dengan menghadapkan tulisan huruf Jepang, "Arigato". Kristal membentuk dengan keindahan yang sama. Selanjutnya ditunjukkan kata "setan", kristal berbentuk buruk. Diputarkan musik Symphony Mozart, kristal muncul berbentuk bunga. Ketika musik heavy metal diperdengarkan, kristal hancur. ${ }^{1}$

Ketika 500 orang berkonsentrasi memusatkan pesan di depan sebotol air, kristal air tadi mengembang bercabang-cabang dengan indahnya. Dan ketika dicoba dibacakan doa Islam, kristal bersegi enam dengan lima cabang daun muncul berkilauan. ${ }^{2}$

Dalam bukunya The Hidden Message in Water. Masaru Emoto menguraikan bahwa air bersifat bisa merekam pesan, seperti pita magnetik atau compact disk. Semakin kuat konsentrasi pemberi pesan, semakin dalam pesan tercetak di air. Air bisa mentransfer pesan tadi melalui molekul air yang lain. ${ }^{3}$

Air kiranya benar-benar dapat memahami maksud dari kata-kata yang diperlihatkan. Dalam hal ini, air merasakan adanya rasa terima kasih. Kemudian membawa informasi yang diterima ke dalam dirinya. Air mengenali kata-kata tidak hanya sebagai sebuah desain sederhana, tetapi juga dapat memahami makna kata tersebut. saat air sadar bahwa kata

${ }^{1}$ annunaki.wordpress.com 13/12/2011: 10.00

${ }^{2}$ Ibid,

${ }^{3}$ Susi Purwoko (Alih bahasa), Pesan Rahasia Sang Air, Gramedia, Jakarta, 2006, 
yang diperlihatkan membawa informasi yang baik, maka air akan membentuk Kristal. Mungkin juga air dapat merasakan perasaan orang yang menulis kata tersebut.

Abdullah Gimnastiar dalam sambutannya penerbitan buku The True Power of Water mengatakan:

Air itu ternyata bisa merespon perlakuan yang diberikan kepadanya, baik berupa kata-kata, tulisan, gambar atau suara. Akhirnya terbukti bahwa bentuk sempurna air adalah heksagonal (segi enam) dengan berbagai hiasan Kristal yang indah bentuknya.

Air heksagonal ialah air yang sangat penting bagi kesehatan karena efek bentuknya. Air ini berperan sebagai antioksidan dengan mengikat radikal bebas $\mathrm{H}+$ dan OH-. Karena itu, jika air ini dikonsumsi, boleh jadi akan muncul reaksi di dalam tubuh, seperti pilek, bersin, batuk, berkeringat dan sering buang air besar maupun kecil. Reaksi seperti ini wajar karena kemungkinan banyaknya racun di dalam tubuh sehingga air heksagonal membersihkannya.

Masaru Emoto dalam penelitiannya juga menemukan bahwa air mengandung efek gelombang energy yang disebut HADO. Lalu dari hado inilah, ia memformat efek energy air untuk menyembuhkan berbagai penyakit. ${ }^{1}$

Pada konsep terbentuknya manusia, telur yang dibubuhi 96\%-nya adalah air. Setelah lahir, 80\% tubuh seorang bayi adalah air. Semakin tubuh manusia berkembang, presentase air

${ }^{1}$ Azam Translator, (terjemah) The True Power of Water 
berkurang dan menetap sampai batas $70 \%$ ketika manusia mencapai usia dewasa ${ }^{1}$. Lebih detailnya, otak $74,5 \%$ air. Darah $82 \%$ air. Tulang yang keras pun mengandung $22 \%$ air. $^{2}$

\section{Kesimpulan}

Atas dasar uraian data tersebut, maka permasalahan fenomena tentang Air Manqib di kalangan Jama'ah Manaqib dapat disimpulkan bahwa:

1. Jama'ah Manqib berkeyakinan bahwa Air Manqib itu mengandung banyak barokah. Oleh karena itu, ia dapat dimanfa'atkan dalam berbagai hal, baik yang sifatnya pengobatan, atau lainnya. Namun demikian, mereka tetap berkeyakinan, bahwa air manaqib itu hanya sekedar perarntara saja, tidak memastikan, yaitu yang diistilahkan dengan sebutan "barokah"

2. Pemanfa'atan air manaqib, jika ditinjau dari sisi agama dapat dibenarkan, dengan catatan tetap berkeyakinan hanyalah sebagai media, bukan penentu, dan yang demikian itu telah disebutkan dalam beberapa ayat Alqur'an, Hadits, dan peraktek para ulama pendahulu,

${ }^{1}$ Ibid. 17

${ }^{2}$ Dikutip dari situs annunaki.wordpress.com/tag/gambar-kristal-airmasaru-emoto/ 13/12/2011: 10.00 
walaupun model perakteknya berbeda, akan tetapi subtansinya sama, yaitu sebagai media (ngalap barokah). Dengan kata lain, pemanfaatan air manaqib, baik ditinjau dari pandangan agama atau sanis dapat dipertanggungjawabkan kebenarannya. 


\section{DAFTAR PUSTAKA}

Al-Quran dan Terjemah. Bandung : J-ART, 2005.

Abidin, Zainal bin Ibrahim. Al Ajwibah al-Gholiyah. Surabaya:Khalista, 2009.

Arikunto, Suharsimi. Manajemen Penelitian. Jakarta: Rineka Cipta, 2007.

Awanah, Abu. Mustakhroj Aby Awanah. Maktabah syamilah.

Barzanjy (al)., Abdul Karim. Faidurrahmani. Surabaya: Al Wava, 2010.

Bayhaqy (al).. Sunan al-Kubro. Maktabah syamilah

Brosur penerimaan santri baru tahun 2011-2012.

Emoto, Masaru. dan Penerjemah: Purwoko, Susi. The Hidden Masseges in Water. Jakarta: PT Gramedia Pusaka utama, 2006.

Penerjemah: Translator, Azam. The True Power of Water. Bandung: MQ Publishing, 2006.

FKI (Forum karya ilmiah Lirboyo). Menjawab Vonis Bid'ah. Kediri Tahta, 2010.

Hadi, Sutrisno. Metodologi Research. Yokyakarta: Universitas Gajah Mada Press,1980.

Hajar, Ibnu. Fathul Bari. Maktabah syamilah.

Hakim (al)., Fikri. Manaqiban Syirik atau Bid'ahkah. Kediri: Al-'Aziziyah, 2009.

Hambali (al)., Ibnu Rajab. Adz Dzail 'Ala Thabaqil Hanabilah. Maktabah Syamilah.

Haqqi. Tafsir haqqi. jz 7. Maktabah syamilah.

Ishaqy (al)., Ahmad Asrori. Pedoman kepemimpinan dan 
kepengurusan. Surabaya: Al Wava, 2011.

Jilany (al)., Abdul Qodir ra. ,Al Ghun-yah. Libanon: Darul Kutub ilmiyah, 1998.

Kaelan. Metode Penelitian Agama. Yokyakarta: Paradigma, 2010.

Malik. Al- Muwattok, jz 4. Maktabah syamilah.

Manawy. Faidhul Qodir. Maktabah syamilah.

Moleong. Metodologi penelitian Kualitatif. Bandung: PT. Remaja Rosdakarya, 2005.

Nazir, Muhammad. Metode Penelitian. Jakarta: Ghalia Indonesia, 1999.

Qurtuby (al). Tafsir Al-Qurtuby. Maktabah syamilah

Ramli, M. Idrus. Membedah Bid'ah \& Tradisi. Surabaya: Khalista, 2010.

Rosidi. Buku saku santri. Surabaya: Al Wava, 2008.

Singarimbun, Masri dan Sofyan Efendi. Metode Penelitian Survai. Jakarta: LP3 ES,1995.

WWW.annunaki.wordpress.com 